(pp. 123-128). Additionally, many errors have crept into the book. To cite just one that I found particularly offensive, he lists "blood" as one of the five sacred products of the cow drunk for purification (p. 219).

Based on three periods of fieldwork conducted between 1973 and 1981, with much of the data now more elegantly analyzed than it was in his 1976 doctoral dissertation (the existence of which is curiously unmentioned), the work contains much of historical interest. It argues well for an approach from the inside out, one grounded in phenomenological ontology and carefully attentive to lessons of chaos theory. Clearly, though, it could have resulted in something much more exciting had Gray continued in the past 15 years to update his material. Since the village Gray studied has been progressively integrated into the urban economy of the Kathmandu valley (as he admits in a footnote written in 1991, the village is becoming "increasingly like a suburb" [p. 12]), the domestic locus of productive activity that Gray explores has been seriously affected by recent urbanization. The detailed analysis of the 1973 elections would be of much greater interest if we could learn how the village factions have evolved throughout recent tumultuous political changes. Despite these limits, Gray's ethnographic component fashions a reasonable, interesting portrait of Chetri life in the Kathmandu Valley in the 1970s, for which little other comparable data exist.

Marriage and Divorce in Islamic South-East Asia. Gavin W. Jones. Oxford: Oxford University Press, 1994. 348 pp.

Laura M. Ahearn

University of Michigan

It will come as no surprise to scholars of Southeast Asia that marriage practices in the region have changed dramatically during the latter half of this century. In his recent book, Marriage and Divorce in Islamic South-East Asia, Gavin W. Jones meticulously documents the various parameters of this trend. Drawing on ethnographies as well as sociological studies, censuses, and surveys, Jones attempts to explain the causes and effects of transformations in patterns of marriage and divorce among Malay-Muslim populations throughout Indonesia, Malaysia, Singapore, Thailand, and Brunei. In brief, Jones uses demographic statistics to argue that the overall trend is away from polygamy and high rates of divorce and toward much later, self-arranged marriage, less control over adolescent women, and greater options for nonmarriage or very late marriage.

A key issue the book attempts to resolve is the extent to which religion influences marriage systems (p. 5). Jones acknowledges the risks involved in creat- ing such an encompassing independent variable but nevertheless concludes that "while difference in Islamic beliefs and practices within the region are important, it should also be stressed that aside from ethnicity and language, Islamic identity, however understood, is the one shared factor among the MalayMuslim populations" (p. 4). The shared identity Jones posits does not seem to act very forcefully or uniformly on patterns of marriage and divorce; indeed, he emphasizes the "profound truth" that "social change is a process not readily divisible into discrete component parts" (p. 161). With regard to divorce, for example, Jones notes that the extremely wide range of divorce rates in Muslim societies around the world is sufficient proof that it is not Islamic law as such that is the cause but rather its propensity to facilitate high divorce in societies that already have a predilection toward the practice (p. 218).

In examining changes in marriage and divorce patterns, Jones also looks at such other factors as female literacy and education, socioeconomic status, labor force participation, and government policies. These he sets out in chapter 2 , along with a historical overview of the region. In the following two chapters Jones focuses on the trend toward increased age at first marriage and its possible causes, arguing that the rise in female age at marriage and the shift to self-arranged marriage reflect the socioeconomic changes taking place in the region, as well as other factors, such as a marriage squeeze in Singapore, the need for education, and the reduction of ideological impediments (p. 159).

Chapters 5 and 6 examine marriage dissolution and influences on the stability of first marriages. Major causes of the recent decline in divorce rates in Islamic Southeast Asia, Jones maintains, include rising ages at marriage and greater self-arrangement of marriage, which in turn are related to socioeconomic factors, such as greater employment of young women away from the home and changing attitudes. Jones argues that new laws and regulations have also played an important role in strengthening an already established trend (p. 264).

Chapter 7 is devoted to polygamy, which does not have a high enough incidence in the region, Jones contends, to have had a major demographic impact. Nevertheless, the possibility rather than the actuality of polygamy has had such an undeniable impact on relationships between wives and husbands that Jones calls it "a touchstone of gender relations and a subject on which women feel very strongly" (p. 286). In chapter 8 Jones explores the effects of changing marriage practices on fertility in different parts of Southeast Asia. He concludes that "in the Malay world, changes in age at marriage and in divorce have been sufficiently dramatic to have had significant effects on fertility, 
though their net effect has been dampened by their mutually offsetting impacts" (p. 302).

Throughout the book Jones relies mainly on quantitative data to paint a picture of important social transformations in Southeast Asia, only occasionally referring to ethnographies or focus group information to give the "feel" of a particular trend. While Jones's command of the material is truly impressive, and while he himself repeatedly warns the reader of the limits of survey data, I could not help but yearn for a study that more thoroughly blended demographic data with rich ethnography. A move toward such anthropological demography can be seen in the work of Tom Fricke, Susan Greenhalgh, and David Kertzer, among others. Nevertheless, by compiling and analyzing such a comprehensive array of data, Jones has done a great service to scholars interested in Southeast Asia or in changing marriage patterns anywhere in the world. As he notes in his conclusion, "there is something to be said for establishing broad patterns and trends, against which further, more specialized studies can test the differences noted for specific subgroups" (p. 304).

Domestic Government: Kinship, Community and Polity in North Yemen. Martha Mundy. London: I. B. Tauris, 1995. $317 \mathrm{pp}$.

\section{ANDREw SHRYOCK}

\section{State University of New York at Buffalo}

Since the 1980s, Yemen has become the site of rich and innovative ethnography. Of works already in print, the most influential are those that abandon the orthodox "village study" for topics that demand interregional and deeply historical frameworks: the qat trade, poetry, textual learning, status hierarchies, and tribe-state relations. Martha Mundy's study is radical in its vigorous rejection of this trend. What Yemeni ethnography needs now, she argues, is close, painstaking, statistically based studies of the political economy of households. In Mundy's view, the household is the seat of "domestic government," a Yemeni political tradition that can be understood only through an intense engagement with local communities.

Mundy's ethnography latches onto a single village, Wadi Dahr, and never lets go. The monograph that results is pieced together with meticulous care. In a manner that is increasingly uncommon, Mundy interweaves hard statistical analysis with intimate accounts of family life. The latter are not as engagingly drawn as one might wish, but the statistical end of Mundy's analysis is superb. Cycles of household economy are given a quantitative dimension that, in the Arab world, is seldom accessible to the ethnographer. The explanatory advantage Mundy gains in developing statistical models can be seen by comparing her chapter on marital alliance with Bourdieu's now classic (and more qualitative) analysis of Kabyle marriage strategies. The movement between narrative and statistical display can, however, be rocky at times. Unfortunately, the appreciation of Mundy's blend of anecdote and number crunching requires the reader to commute endlessly between the book's main text and its 69 tables and figures, many of which reside in faroff appendixes. The book is certainly information rich, but it is not always easy to read.

Like the village it portrays, Mundy's approach is confidently old-fashioned. "Its aim is not novelty of method but care and quality of documentation" (p. 5). Mundy embraces a model of domestic production reminiscent of Jack Goody's work on family history in Eurasia, an approach that locked into its current holding pattern over 20 years ago. Mundy's analysis is empirical, averse to formal models, attentive to property rights, and keen to link Wadi Dahr to the larger world of "peasant production." This approach is described as social history, but Mundy's analysis dwells steadfastly on the ethnographic present of 1973-77. Changes that have taken place since then, especially the nationalization of tribal politics and the growing power of tribal shaykhs, are depicted as ominous (even malign) developments. Mundy refuses to face them squarely, and the scholars who do confront them she criticizes for perpetuating segmentary models of tribalism. That the "peasants" of Wadi Dahr are tribespeople is obviously a sticky issue for Mundy. She handles it by means of elaborate circumlocutions. The term "tribe" (qabilah) usually appears in scare quotes, as if it had no local correlate; tribesmen ( $q a b a^{\prime} i l$ ) are called "arms-bearing farmers"; and tribal confederations become "rural political alliances." Terminological cloaking of this sort distorts local meanings. Tribal politics and "domestic government" are not inevitably the same thing, but they are part of the same political system. Mundy neglects to tell us how or why.

In fact, the articulation of "domestic government" with wider notions of political and economic life (an event the reader is promised on the book's dust jacket) never quite materializes. The worlds of statecraft and law are cast as social frameworks that impinge on the household. Yet the reverse movement, in which "domestic government" informs both law and state, is barely taken up, even though Yemen's political economy is effectively controlled, now as in the past, by a handful of prominent families. Mundy does not wish to explore these issues. They call for the same transcendence of place she finds problematic in Yemeni ethnography. But the power of Mundy's analysis invites us to apply it beyond the fields and irrigation ditches of Wadi Dahr. The ultimate impact of Domes- 